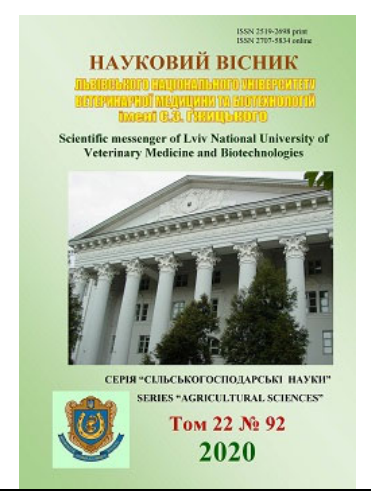

Науковий вісник Львівського національного університету ветеринарної медищини та біотехнологій імені С.3. Гжицького. Серія: Сільськогосподарські науки

Scientific Messenger of Lviv National University of Veterinary Medicine and Biotechnologies. Series: Agricultural sciences doi: $10.32718 /$ nvlvet-a9202

https://nvlvet.com.ua/index.php/agriculture

UDC 661.155.3: 636.3: 577.12

\title{
Scientific and practical aspects of the use of prebiotics in the process of feeding ruminants
}

\author{
S. O. Vovk, I. V. Polovyi
}

Institute of Agriculture of the Carpathian region of the National Academy of Agrarian Sciences of Ukraine, Obroshyno, Ukraine

Article info

Received 27.01.2020

Received in revised form 26.02.2020

Accepted 27.02.2020

Institute of Agriculture of the Carpathian region of the National Academy of Agrarian Sciences of Ukraine Grushevskogo Str., 5 , Obroshyno, Pustomytovsky District, Lviv Region, 81115, Ukraine.

Tel.: +38-096-938-84-03 E-mail:vovkstah@gmail.com
Vovk, S. O., \& Polovyi, I. V. (2020). Scientific and practical aspects of the use of prebiotics in the process of feeding ruminants. Scientific Messenger of Lviv National University of Veterinary Medicine and Biotechnologies. Series: Agricultural sciences, 22(92), 9-14. doi: 10.32718/nvlvet-a9202

The review article presents current literature data on the classification of prebiotics. Information on the characteristics of the most common and used in the feeding of ruminants prebiotic drugs is presented. Based on literature, attention is drawn to the fact that one of the main functions of mannan oligosaccharides is their competitive binding to gram-negative bacteria of the pancreas and cecum in ruminants and inhibition of pathogenic microbiota growth in these departments of gastrointestinal tract. Fructooligosaccharides are not digested by animals, starting from the oral cavity and ending with the intestines. They are readily available substrates for the microflora of the ruminant pancreas and large intestine of animals. As for galactosyloligosaccharides, experiments have convincingly proven that they stimulate the growth and development of bifidobacteria and lactobacilli, enterobacteria and streptococci in the digestive tract of animals. Lactulose and lactiol as prebiotics have a positive effect on feed intake in young animals, changing the microbial balance and biochemical composition of the contents of the cecum. These prebiotics promote the reproduction of gram-positive bacteria in the digestive tract of animals and inhibit the growth and development of clostridia. Lactulose and lactiol activate the formation of short-chain fatty acids by the microbiota of the cecum of animals, as well as increase the permeability of the intestinal mucosa and the solubility of minerals in the colon. High molecular weight beta-glucans enhance the phagocytic, cytotoxic and antimicrobial activity of macrophages. They help to produce reactive intermediates of oxygen and nitrogen and clean the tissues of apoptotic cells. Furthermore, stimulating innate immune responses, beta-glucans increase the production of anti-inflammatory cytokines and chemokines. Inulin in ruminants has a pronounced activating effect on the immune system, as well as activates the production of short-chain fatty acids in the pancreas and large intestine. The biological mechanism of action in the digestive tract of ruminants of such prebiotics as: mannan oligosaccharides, fructooligosaccharides, galactooligosaccharides, lactulose, lactiol, betaglucans, inulin is described. The productive effect of prebiotics when using their additives in the diets of young and adult ruminants is characterized. It is shown that the use of the above prebiotic drugs in the feeding of ruminant species selectively stimulates the metabolic processes of the symbiotic microflora of the pancreas and cecum, activates their vital functions and growth. The use of prebiotic supplements in the diets of cows stimulates milk productivity and improves milk quality. In fattening cattle, the stabilization of the $\mathrm{pH}$ of the scar content through the use of prebiotics increases the average daily gain and live weight of animals and the efficiency of assimilation of nutrients in feed.

Key words: prebiotics, ruminants, feeding, metabolic and productive action.

\section{Науково-практичні аспекти використання пребіотиків у годівлі жуйних тварин}

\author{
С. О. Вовк, І. В. Польовий
}

Інститут сільського господарства Карпатського регіону НААН, с. Оброшино, Львівська область, Пустомитівський район, Украӥна 
В оглядовій статті наведено сучасні літературні дані шчодо класифікачії пребіотиків. Наведена інформація із характеристики найбільш поширених і вживаних у годівлі жуйних тварин пребіотичних препаратів. Виходячи із літературних джерел, акцентується увага на тому, шо однією з основних функиій мананових олігосахаридів є ї конкурентне зв'язування з грам негативними бактеріями передшлунків і сліпої кишки у жуйних та пригнічення росту патогеної мікробіоти у вказаних відділах травного тракту. Фруктоолігосахариди не піддаються перетравленню у тварин, починаючи з ротової порожнини $i$ закінчуючи кишечником. Вони є легкодоступними субстратами для мікрофлори передилунків жуйних і товстого кишечнику тварин. Що стосується галактозилолігосахаридів, експериментами переконливо доведено, шо вони у травному тракті тварин стимулюють ріст і розвиток біфідо- й лактобактерій, ентеробактерій та стрептококів. Лактулоза і лактіол як пребіотики позитивно впливають на споживання корму в молодняку тварин, змінюючи мікробний баланс та біохімічний склад вмісту сліпої кишки. Вказані пребіотики сприяють розмноженню у травному тракті тварин грам позитивних бактерій і пригнічують ріст та розвиток клостридій. Лактулоза і лактіол активують утворення коротколанцюгових жирних кислот мікробіотою сліпої кишки тварин, а також підвищують проникність слизової оболонки кишечнику і розчинність мінералів в товстій кишиі. Бета-глюкани, які мають велику молекулярну масу, посилюють фагоцитарну, циитотоксичну та антимікробну активність макрофагів. Вони допомагають виробляти реактивні проміжні сполуки кисню і азоту та очищати тканини від апоптичних клітин. Крім стимулювання вроджених імунних реакцій, бета-глюкани збільшують продукцію протизапальних цуитокінів і хемокінів. Інулін в організмі жуйних тварин виявляє виражену активуючу дію на імунну систему, а також активує продукцію жирних кислот з коротким ланцюгом у передщлунках та товстому кишечнику. Описано біологічний механізм дї у травному тракті жуйних тварин таких пребіотиків, як: мананові олігосахариди, фруктоолігосахариди, галактоолігосахариди, лактулоза, лактіол, бета-глюкани, інулін. Охарактеризована продуктивна дія пребіотиків при використанні їхніх добавок у раціонах годівлі молодняку і дорослих жуйних тварин. Показано, щзо використання наведених вище пребіотичних препаратів у годівлі жуйних видів тварин вибірково стимулює перебіг метаболічних процесів симбіотичної мікрофлори передшлунків і сліпої китки, активує їх життєдіяльність і ріст. Використання пребіотичних добавок у раціонах корів стимулює молочну продуктивність та поліпшує якість молока. У відгодівельної великої рогатої худоби стабілізація рН рубиевого вмісту за рахунок використання пребіотиків підвищує середньодобові прирости й живу масу тварин та ефективність засвоєння поживних речовин корму.

Ключові слова: пребіотики, жуйні тварини, годівля, метаболічна і продуктивна дія.

\section{Вступ}

Пребіотики - це неперетравлювані складові компоненти різних видів мікроорганізмів та деяких рослин, які селективно стимулюють життєдіяльність мікрофлори у різних відділах травного тракту тварин. На відміну від пробіотиків, пребіотики виявляють стимулюючий ефект на метаболічну активність наявної у травному тракті мікробіоти, сприяючи при цьому іiі активному росту і розвитку. Однією із важливих переваг пребіотиків $є$ те, що вони стійкі до кислотності шлунка та абсорбції і гідролізу ферментами шлунково-кишкового тракту тварин.

У жуйних тварин пребіотики активують ферментативну активність мікроорганізмів передшлунків і насамперед рубця, оптимізують рН кишечнику і тим самим пригнічують розвиток патогенних бактерій, позитивно впливають на імунні властивості кишковоасоційованих тканин і лімфоїдних органів.

На даний час вітчизняні і зарубіжні фірми для потреб тваринництва пропонують широкий спектр різних пребіотичних препаратів, до складу яких входять: мананові олігосахариди, фруктоолігосахариди, галактоолігосахариди, лактулоза, лактіол, бета-глюкани, інулін та інші.

\section{1. Загальна характеристика пребіотиків.}

Мананові олігосахариди

Мананові олігосахариди - це коротколанцюгові низькомолекулярні вуглеводні фрагменти клітинної стінки дріжджів Saccharomyces cerevisiae. Манани становлять приблизно 30 \% маси клітинної стінки і містяться на іiі зовнішніх мембранах (Egorov \& Mokrinskaya, 2010; Polishchuk \& Bulavkina, 2010; Tarasenko \& Filippova, 2014; Singh et al., 2017). Вони складаються з безлічі $\alpha-1,2$ і $\alpha-1,3$ N-пов'язаних гліканових бічних ланцюгів, приєднаних до $\alpha-1,6$ зв'язаного мономеру манози (Singh et al., 2017). Для отримання маннанових олігогосахаридів клітини дріжджів лізують і отриману культуру центрифугують для виділення компонентів клітинної стінки. Компоненти клітинної стінки промивають і сушать шляхом розпилення (Singh et al., 2017).

\section{Фруктоолігосахариди}

Фруктоолігосахариди - це хімічні речовини із класу фруктанів. Вони мають низьку молекулярну масу і невисокий рівень полімеризації (Sethy et al., 2017). Коротколанцюгові фруктоолігосахариди отримують шляхом ферментації сахарози. Як сировину для іiі виробництва використовують цукрові буряки або цукрову тростину, які багаті на вміст сахарози (Egorov \& Mokrinskaya, 2010; Sethy et al., 2017).

\section{Галактоолігосахариди}

Галактоолігосахариди містять широкий спектр цукрів від дисахаридів до октасахаридів. Біологічна дія комерційних галактоолігосахаридів в організмі молодняку тварин подібна до дії аналогічних сполук материнського молока у травному тракті дітей (Sharon \& Ofek, 2000).

\section{Лактулоза}

Лактулоза є напівсинтетичним дисахаридом, який переважно продукується лактобацилами або біфідобактеріями. Лактулоза складається з галактози і фруктози. Це пребіотичний вуглевод, який стимулює ріст і розвиток корисної мікрофлори в шлунковокишковому тракті та водночас пригнічує ріст патогенних бактерій, таких як сальмонели. Лактулозу зазвичай отримують 3 лужного розчину лактози шляхом ii хімічної ізомеризації та методами ферментативної ізомеризації з використанням b-галактозидаз (Schuster-Wolff-Bühring et al., 2010).

\section{Лактіол}

Лактіол отримують із лактози шляхом іiї гідролізу. Згодовування лактіолу молодняку тварин стимулює життєдіяльність біфідобактерій $\mathrm{i}$ лактобактерій та зменшує чисельність бактероїдів видів Clostridia у травному тракті (Ouwehand \& Vesterlund, 2004). 
Бета-глюкани

Бета-глюкани - це полімери глюкози клітинної стінки дріжджів Saccharomyces cerevisiae та зерна злаків, таких як ячмінь і овес (Singh et al., 2017), що складаються $3 \quad \beta-1, \quad 3$ i $\beta-1, \quad 6$ пов'язаних Dглюкопіранозильних одиниць. На них припадає від 50 до $60 \%$ маси клітинної стінки дріжджів. На відміну від мананових олігосахаридів, бета-глюкани містяться у внутрішній частині клітинної стінки. Вони забезпечують їі структуру і щільність (Sethy et al., 2017; Singh et al., 2017). Біологічна дія бета-глюканів у травному тракті тварин визначається ступенем їх розгалуження, молекулярною масою і третинною структурою (Russo et al., 2012).

\section{Інулін}

Інулін - це рослинний фрукто-олігосахарид із класу фруктанів, який містить 6-10\% цукрів, таких як глюкоза, фруктоза і сахароза. Травні ферменти шлунка та кишечнику тварин не здатні розщеплювати глюкозидні зв'язки інуліну. У рослинних клітинах інулін виконує енергетичну і кріопротекторну функції (Van Loo et al., 1995). Рослини містять інуліни $з$ різною довжиною вуглеводного ланцюга, наприклад: у пшениці, цибулі, бананах наявні коротколанцюгові інуліни; у часнику та топінамбурі - середньоланцюгові; у артишоку та цикорію - довголанцюгові (Van Loo et al., 1995).

2. Особливості біологічної дії різних класів пребіотиків у травному тракті жуйних тварин.

\section{Мананові олігосахариди}

Однією з основних функцій мананових олігосахаридів є їхнє конкурентне зв'язування з грам негативними бактеріями. Останні легко приєднуються до Dманозних рецепторів олігосахаридів на епітелії шлунково-кишкового тракту (Friman et al., 1996). У подальшому такий комплекс відділяється від слизової оболонки і виходить з травного тракту, істотно знижуючи в ньому наявність патогенної мікрофлори (Spring et al., 2000). Мананові олігосахариди виявляють виражену фагоцитарну та імуномодулюючу дію в організмі тварин (Franklin et al., 2005).

Фруктоолігосахариди, галактоолігосахариди, лактулоза, лактіол

Проведеними науковими дослідженнями доведено, що фруктоолігосахариди не піддаються перетравленню у тварин, починаючи з ротової порожнини і закінчуючи кишечником (Czaczyk, 2003). Встановлено, що ферменти слини, шлунку і слизової кишечнику тварин не здатні гідролізувати $\beta-(1-2)$ зв'язки фруктозилфруктози (Czaczyk, 2003). Показано, що фруктозилолігосахариди $\epsilon$ легкодоступними субстратами для мікрофлори передшлунків жуйних і товстого кишечнику тварин (Czaczyk, 2003).

Що стосується галактозилолігосахаридів, експериментами переконливо доведено, що вони у травному тракті тварин стимулюють ріст і розвиток біфідой лактобактерій, ентеробактерій та стрептококів (Hopkins et al., 1998).

Лактулоза i лактіол як пребіотики позитивно впливають на споживання корму у молодняку тварин, змінюючи мікробний баланс та біохімічний склад вмісту сліпої кишки (Seki et al., 2007). Дослідження in vivo продемонстрували, що вказані пребіотики сприяють розмноженню у травному тракті тварин грам позитивних бактерій, що в основному належать до родів Bifidobacterium і Lactobacillus. Вони також пригнічують ріст і розвиток таких штамів хвороботворних бактерій, як Clostridium (Bouhnik, 2004). Лактулоза і лактіол активують утворення коротколанцюгових жирних кислот мікробіотою сліпої кишки тварин, а також підвищують проникність слизової оболонки кишечнику і розчинність мінералів в товстій кишці (Seki et al., 2007).

Бета-глюкани

Експериментальними дослідженнями показано, що бета-глюкани, які мають велику молекулярну масу, посилюють фагоцитарну, цитотоксичну та антимікробну активність лейкоцитів, зокрема макрофагів (Brown \& Gordon, 2003). Вони допомагають виробляти реактивні проміжні сполуки кисню і азоту та очищати тканини від апоптичних клітин (Brown \& Gordon, 2003; Gantner et al., 2005). Крім стимулювання вроджених імунних реакцій, бета-глюкани збільшують продукцію протизапальних цитокінів і хемокінів та сприяють доступу лейкоцитів до місць інфекційних уражень (Vetvicka \& Yvin, 2004).

Механізм, за допомогою якого бета-глюкани стимулюють імунні відповіді, належить до рецептора Дектин-1. Рецептор Дектин-1 експресується на моноцитах, макрофагах, нейтрофілах, дендритних клітинах та Т-клітинах селезінки і може розпізнавати вуглеводи з $\beta-1,3$ і $\beta-1,6$ глюкановими зв'язками (Gantner et al., 2005; Sonck et al., 2009). Коли бета-глюкани зв'язуються з Дектином-1, вони стають фосфорильованими і таким чином індукують фагоцитоз (Brown \& Gordon, 2003).

Інулін

Інулін в організмі тварин виявляє виражену активуючу дію на імунну систему безпосередньо або опосередковано. Непрямим впливом інуліну як пребіотика $є$ стимуляція росту і розвитку корисної мікрофлори кишечнику, а також інгібування проліферації патогенної мікробіоти, що призводить до збільшення кількості корисних біфідобактерій та зменшення популяції патогенних бактерій (Berg, 1985). Прямий ефект включає стимулюючий вплив інуліну на фагоцитоз, що здійснюється фагоцитарними клітинами крові (Wójcik et al., 2007) та неспецифічними механізмами гуморального імунітету (Milewski et al., 2007).

Інулін також активує продукцію жирних кислот 3 коротким ланцюгом у передшлунках жуйних та товстому кишечнику моногастричних тварин, підкислює середовище ободової і товстої кишок, сприяючи виробленню муцину в кишково-асоційованих лімфоїдних тканинах (Lomax \& Calder, 2009). Доведено, що інулін інтенсифікуе продукцію цитокінів клітинами селезінки і виявляє стимулюючу дію на імунну реакцію щодо канцерогенних агентів (Watzl et al., 2005).

3. Продуктивна і метаболічна дія пребіотиків за використання їх добавок у раціонах годівлі жуйних тварин.

Пребіотики у раціонах годівлі молодняку

Відомо, що періоди новонародження та переходу від молочної до рослинної годівлі є особливо важли- 
вими у вирощуванні молодняку тварин. Тому ефективне використання добавок пребіотиків у складі раціонів годівлі телят, ягнят і козенят дозволяе стимулювати процеси перебігу обміну речовин у їхньому організмі, посилити імунний захист, знизити захворюваність інфекційними і незаразними захворюваннями, підвищити інтенсивність росту i розвитку тварин (Karput \& Babina, 2008; Mukhina et al., 2008; Malkoch et al., 2014; Kravchenko et al., 2014; Uyeno et al., 2015; Svitenko \& Kucheriavy, 2016; Sethy et al., 2017; Singh et al., 2017).

Проведеними дослідженнями показано, що введення фруктоолігосахаридів у раціони телят знижує частоту захворюваності та ступінь вираженості перебігу клінічних ознак кишкових інфекцій шляхом пригнічення розмноження патогенних ентеробактерій кишечника (Quigley et al., 2002). Встановлено також, що додавання галактозил-лактози до замінників молока виявляє стимулюючий вплив на ріст та здоров'я телят у молочний період живлення (Quigley et al., 1997).

Використання у складі цільного молока для годівлі телят голштинської породи добавок целоолігосахаридів, що містили у своєму складі глюкозу з $\beta-1-4$ зв'язками, сприяло збільшенню у кишечнику тварин числа бактерій, які продукують масляну кислоту (Louis \& Flint, 2009). Дослідженнями інших авторів показано, що використання вказаних олігосахаридів у складі цільного молока істотно збільшувало середньодобові прирости і ефективність використання кормів у телят (Hasunuma et al., 2011). На думку дослідників, це пов'язано з посиленням ферментації у рубці, внаслідок чого рівень коротколанцюгових жирних кислот, у тому числі пропіонату, в рубцевій рідині телят, які отримували олігосахариди, був значно вищим ніж у телят, які не одержували таких добавок (Hasunuma et al., 2011).

У дослідженнях на новонароджених телятах показано, що введення добавок бета-глюканів до випоюваного молока підвищує у них $\mathrm{pH}$ рубця і засвоюваність поживних речовин (Kim et al., 2011). Мананові олігосахариди, додані до молочної суміші для телят, підвищують приріст їхньої маси тіла і споживання корму (Ghosh \& Mehla, 2012). Введення до замінника молока добавок синтетичної лактулози підвищує середньодобові прирости маси тіла телят і поліпшує склад мікрофлори кишечнику, стимулюючи при цьому ріст чисельності пробіотичних бактерій (Fleige et al., 2007).

Добавки фруктоолігосахаридів до раціонів телят підвищують їх продуктивність за рахунок покращення трансформації поживних речовин кормів в організмі, що сприяє зростанню маси тіла (Grand et al., 2013). Інулін і лактоза пригнічують експресію мРНК генів патогенних мікроорганізмів у травному тракті телят, що істотно знижує у них виникнення запальних процесів слизової кишківника (Masanetz et al., 2011).

Показано, що манан-олігосахариди та бетаглюкани, введені до складу замінників молока, стимулюють імунну систему телят і таким чином знижують частоту і тяжкість ентеральних захворювань (Quigley et al., 2002).
Використання лактулози у складі замінників молока для телят справляє імунномодулюючу дію на кількісний склад Т-клітин у імунних структурах шлунково-кишкового тракту та активує експресію мРНК протизапальних цитокінів (Fleige et al., 2007). Дослідженнями вказаних авторів показано, що у бичків, які отримували у складі раціону лактулозу, у слизовій оболонці клубової кишки істотно зросла транскрипція Fc-рецептора IgA (Fleige et al., 2007).

Доведено, що використання добавок інуліну і лактози в молочних сумішах для телят підвищує рівень гемоглобіну в крові, активує експресію мРНК маркерів слизової тонкого кишківника, пов'язаних з інгібуванням запальних процесів а також посилює експресію мРНК інтерлейкіну в мезентеріальних лімфатичних вузлах клубової кишки (Masanetz et al., 2011).

Згодовування телятам у складі молока мананолігосахаридів істотно підвищує у плазмі крові рівень IgG (Lazarevic, 2010). Використання у раціоні телят добавок гідролізованих дріжджів Saccharomyces cerevisiae підвищує у крові концентрацію імуноглобулінів IgA i IgG (Kim et al., 2011).

3.2 Пребіотики у раціонах годівлі дорослих тварин

Добавки пребіотиків у раціонах годівлі дорослих тварин використовуються в значно меншій мірі, ніж у молодняка, і вони в основному використовуються 3 метою стимуляції життєдіяльності симбіотичних мікроорганізмів рубцевого середовища жуйних. Пребіотики позитивно впливають на процеси рубцевого травлення, особливо целюлоліз та синтез мікробних білків. Найбільш поширеними пребіотиками, які використовуються у раціонах годівлі великої рогатої худоби, є продукти, отримані зі штамів дріжджів Saccharomyces cerevisiae (Mukhina et al., 2008; Bezpalko, 2012; Bezpalko, 2013).

Механізм дії дріжджевих пребіотиків ще не з'ясований детально, проте доведено, що вони активують швидкість ферментативних процесів у симбіотичної мікрофлори рубця (Uyeno et al., 2015). Пребіотичні препарати, отримані зі штамів дріжджів Saccharomyces cerevisiae особливо ефективні для стабілізації рН вмісту рубця та стимулювання метаболічної активності популяції найпростіших, які швидко поглинають крохмаль і таким чином ефективно конкурують з бактеріями, що продукують лактат (Desnoyer et al., 2009; Robinson \& Erasmus, 2009; Bezpalko, 2012; Bezpalko, 2013; Uyeno et al., 2015). Дріжджеві пребіотики змінюють процес бродіння в рубці - зменшують утворення газу метану (Uyeno et al., 2015). Вказані пребіотики стимулюють ріст і розвиток рубцевої мікрофлори, яка продукує органічні кислоти, олігосахариди, вітаміни групи В, амінокислоти і тим самим опосередковано підвищують целюлозолітичну активність бактерій (Uyeno et al., 2015).

Використання добавок дріжджевих пребіотиків у раціонах корів підвищує їхню молочну продуктивність (Desnoyer et al., 2009; Bezpalko, 2012; Bezpalko, 2013). Позитивним ефектом добавок дріжджевих пребіотиків до раціонів корів є зростання ферментації клітковини у вмісті рубця (Desnoyer et al., 2009; Robinson \& Erasmus, 2009; Bezpalko, 2012; Bezpalko, 2013). 
У відгодівельної великої рогатої худоби стабілізація $\mathrm{pH}$ рубцевого вмісту за рахунок використання у іiі раціонах добавок дріжджевих пребіотиків підвищує ефективність засвоєння поживних речовин корму, внаслідок чого зростають середньодобові прирости й жива маса тварин (Uyeno et al., 2015).

\section{Висновки}

Підсумовуючи наведені вище результати наукових досліджень останніх років, варто зазначити, що використання пребіотиків у раціонах жуйних тварин активує метаболічні процеси у симбіотичної мікрофлори передшлунків та стимулює інтенсивність іiі розмноження. Вказані біодобавки сприяють засвоєнню мінеральних речовин, поліпшують гомеостаз ліпідів і глюкози в організмі, стимулюють імунний захист у тварин. Враховуюючи позитивну метаболічну і продуктивну дію пребіотиків при використанні їхніх добавок у раціонах годівлі жуйних тварин, подальші наукові дослідження необхідно скерувати на вивчення молекулярних механізмів їх біологічного ефекту, взаємодії із генетичними профілями мікрофлори травного тракту і тканинних структур органів тваринигосподаря. Значний науково-практичний інтерес становлять також дослідження, спрямовані на розширення діапазону класів пребіотиків, вивчення їхнього впливу на перебіг обміну речовин та продуктивні якості тварин залежно від виду, статі, віку, фізіологічного стану, аліментарних факторів.

\section{References}

Berg, R. D. (1985). Indogenous intestinal microflora and the host immune response. J. Immunopharmacol, 4, 161-168.

Bezpalko, A. V. (2012) Effect of feed additive Actisaf Cz 47 on dairy productivity of high-yielding cows, compared to baker's dry yeast. Bulletin of the Zhytomyr National Agro-Ecological University, 2(33), 104-106 (in Ukrainian).

Bezpalko, A. V. (2013). Influence of yeast crops on dairy productivity of cows during heat stress. Materials III International scientific-practical conference "Zootechnical science: history, problems, prospects". Kamianets-Podilskyi, 22-23 (in Ukrainian).

Bouhnik, Y. (2004). Lactulose ingestion increases faecal bifidobacterial counts: a randomised double-blind study in healthy humans. Eur. J. Clin. Nutr, 58(3), 1658-1664. doi: 10.1038/sj.ejcn.1601829.

Brown, G. D., \& Gordon, S. (2003). Fungal $\beta$-glucans and mammalian immunity. Immunity, 19(3), 311-315. doi: 10.1016/S1074-7613(03)00233-4.

Czaczyk, K. (2003). The creating biofilms of bacteria the creature the phenomenon and mechanisms of influences. Biotechnology, 3, 180-192.

Desnoyer, M., Giger-Reverdin, S., Bertin, G., DuvauxPonter, C., \& Sauvant, D. (2009). Meta-analysis of the influence of Saccharomyces cerevisiae supplementation on ruminal parameters and milk production of ruminants. J. Dairy. Sci., 92(4), 1620 1632. doi: $10.3168 /$ jds.2008-1414.
Egorov, B. V., \& Mokrinskaya, A. V. (2010). Modern alternatives to feed antibiotics. Cereal products and compound feeds, 3, 27-34 (in Ukrainian).

Fleige, S., Preißinger, W., Meyer, H. H., \& Pfaffl, M. W. (2007). Effect of lactulose on growth performance and intestinal morphology of preruminent calves using a milh replacer conteining Enterococcus facium. Anim. Sci., 1(3), 367-373. doi: 10.1017/S1751731107661850.

Franklin, S. T., Newman, M. C., Newman, K. E., \& Meek, K.I. (2005). Immune parameters of dry cows fed mannan oligosaccharide and subsequent transfer of immunity to calves. J. Dairy Sci., 88(2), 766-775. doi: 10.3168/jds.S0022-0302(05)72740-5.

Friman, V., Adlerberth, I., Connell, H., Svanborg, C., Hanson, L. A., \& Wold, A. E. (1996). Decreased expression of mannose-specific adhesins by Escherichia coli in the colonic microflora of immunoglobulin A-deficient individuals. Infect. Immun., 64(7), 2794-2798. https://www.ncbi.nlm.nih. gov/pubmed/8698510.

Gantner, B. N., Simmons, R. M., \& Underhill, D. M. (2005). Dectin-1 mediates macrophage recognition of Candida albicans yeast but not filaments. Embo J. 24(6), 1277-1286. doi: 10.1038/sj.emboj.7600594.

Ghosh, S., \& Mehla, R. K. (2012). Influence of dietary supplementation of prebiotics (mannanoligosaccharide) on the performance of crossbred calves. Trop. Anim. Health Prod., 44, 617 622. doi: 10.1007/s11250-011-9944-8.

Grand, E., Respondek, F., Martineau, C., Detilleux, J., \& Bertrand, G. (2013). Effects of short-chain fructooligosaccharides on growth performance of preruminant veal calves. J. Dairy Sci., 96(2), 1094 1099. doi: 10.3168/jds.2011-4949.

Hasunuma, T., Kawashima, K., Nakayama, H., Murakami, T., Kanagawa, H., Ishii, T., Akiyama, K., Yasuda, K., Terada, F., \& Kushibiki, S. (2011). Effect of cellooligosaccharide or synbiotic feeding on growth performance, fecal condition and hormone concentrations in holstein calves. Anim Sci J., 82(4), 543-548. doi: 10.1111/j.1740-0929.2010.00861.x.

Hopkins, M. J., Cummings, J. H., \& Macfarlane, G. T. (1998). Inter-species differences in maximum specific growth rates and cell yields of bifidobacteria cultured on oligosaccharides and other simple carbohydrate sources. Journal of Applied Microbiology, 85(2), 381386. doi: 10.1046/j.1365-2672.1998.00524.x.

Karput, I. M., \& Babina, M. P. (2008). Pro- and prebiotics in increasing resistance, stimulation of growth and prevention of young diseases. Vitebsk State Academy of Veterinary Medicine,4(2), 87-89 (in Russian).

Kim, M. H., Seo, J. K., Yun, C. H., Kang, S. J., Ko, J. Y., \& Ha, J. K. (2011). Effects of hydrolyzed yeast supplementation in calf starter on immune responses to vaccine challenge in neonatal calves. Animal. Sci., 5(6), 953-960. doi: 10.1017/S1751731110002673.

Kravchenko, N. O., Dmitruk, O. M., \& Bozhok, L. V. (2014). Influence of prebiotics on the biological activity of lactic acid bacteria. Agricultural Microbiology, 20, 54-59 (in Ukrainian). 
Lazarevic, M. (2010). Effect of gut active carbohydrates on plasma $\mathrm{IgG}$ concentrations in piglets and calves. Animal Sci., 4(6), 938-943. doi: 10.1017/S1751731110000194.

Lomax, A. R., \& Calder, P. C. (2009). Prebiotics, immune function, infection and inflammation. A review of the evidence. Br. J. Nutr., 101(5), 633-658. doi: $10.1017 / \mathrm{S} 0007114508055608$.

Louis, P., \& Flint, H. J. (2009). Diversity, metabolism and microbial ecology of butyrate-producing bacteria from the human large intestine. FEMS Microbiol Lett., 294(1), 1-8. doi: 10.1111/j.1574-6968.2009.01514.x.

Malkoch, S. V., Belmer, T. V., \& Gasilina, A. V. (2014). The importance of prebiotics for the functioning of the intestinal microflora. Agricultural Mikrobiology, 20, 59-63 (in Russian).

Masanetz, S., Preißinger, W., Meyerand, H. H. D. \& Pfaffl, M. W. (2011). Effects of the prebiotics inulin and lactulose on intestinal immunology and hematology of preruminant calves. Animal Sci., 5(7), 1099-1106. doi: 10.1017/S1751731110002521.

Milewski, S., Wójcik, R., Małaczewska, J., Trapkowska, S., \& Siwicki, A. K. (2007). Effect of $\beta-1.3 / 1.6-D-$ glucan on meat performance and non-specific humoral defense mechanisms in lambs. Med. Vet., 63(3), 360 363. https://www.cabdirect.org/cabdirect/abstract/ 20073053051 .

Mukhina, N., Lunegova, I. V., \& Sidorov, M. V. (2008). Prebiotics - the way to increase the productivity of cattle. Actual problems of intensive development of livestock breeding. Gorki, 11, 50-55 (in Russian).

Ouwehand, A., \& Vesterlund, S. (2004). Antimicrobial components from lactic acid bacteria. Food Science and Technology, 139, 375-396. doi: 10.1201/9780824752033.ch11.

Polishchuk, A. A., \& Bulavkina, T. P. (2010). Modern feed additives in animal and poultry feeding. Bulletin of the Poltava State Agrarian Academy. Poltava, 2, 63-66 (in Ukrainian).

Quigley, J. D., Drewry, J. J., \& Murray, L. M., \& Ivey, S. J. (1997). Body weight gain, feed efficiency, and fecal scores of dairy calves in response to galactosyl-lactose or antibiotics in milk replacers. J. Dairy Sci., 80(8), 1751-1754. doi: 10.3168/jds.S0022-0302(97)76108-3.

Quigley, J. D., Kost, C. J., Wolfe, T. A. (2002). Effects of spray-dried animal plasma in milk replacers or additives containing serum and oligosaccharides on growth and health of calves. J. Dairy Sci., 85(2), 413421. doi: 10.3168/jds.S0022-0302(02)74089-7.

Robinson, P. H., \& Erasmus, L. J. (2009). Effects of analyzable diet components on responses of lactating dairy cows to Saccharomyces cerevisiae based yeast products: A systematic review of the literature. Anim. Feed Sci. Technol., 149(3-4), 185-198. doi: 10.1016/j.anifeedsci.2008.10.003.

Russo, P., López, P., Capozzi, V., de Palencia, P. F., Dueñas, M. T., Spano, G., \& Fiocco, D. (2012). Betaglucans improve growth, viability and colonization of probiotic microorganisms. Int. J. Mol. Sci., 13(5), 6026-6032. doi: 10.3390/ijms13056026.
Schuster-Wolff-Bühring, R., Fischer, L., \& Hinrichs, J. (2010). Production and physiological action of the disaccharide lactulose. Int. Dairy J., 2(11), 731-741. doi: 10.1016/j.idairyj.2010.05.004.

Seki, N., Hamano, H., Iiyama, Y., Asano, Y. Kokubo, S., Yamauchi, K., Tamura, Y., Uenishi, K., \& Kudou, H. (2007). Effect of lactulose on calcium and magnesium absorption: a study using stable isotopes in adult men. J. Nutr. Sci., 53(1), 5-12. doi: 10.3177/jnsv.53.5.

Sethy, K., Dhaigude, V., Duibedi, B. et al. (2017). Prebiotics in animal feeding. The Pharma Innovation Journal, 6(11), 482-486.

Sharon, N., \& Ofek, I. (2000). Safe as mother's milk: Carbohydrates as future anti-adhesion drugs for bacterial diseases. Glycoconj J., 17(7-9), 659-665. doi: 10.1023/a:1011091029973.

Singh, A., Kerketta, S., \& Yogi, R. (2017). Prebiotics The New Feed Supplement for Dairy Calf. International Journal of Livestock Research, 7(8), 1-17. doi: 10.5455/ijlr.20170610051314.

Sonck, E., Stuyven, E., Goddeeris, B., \& Cox, E. (2009). Identification of the porcine C-type lectin dectin-1. Vet. Immunol. Immunopathol, 130(1-2), 131-134. doi: 10.1016/j.vetimm.2009.01.010.

Spring P., Wenk, C.' Dawson, K. A., \& Newman, K. E. (2000). The effects of dietary mannanonoligosaccharides on cecal parameters and the concentrations of enteric bacteria in the cecal of Salmonella-challanged broiler chicks. Poultry Sci., 79(2), 205-211. doi: 10.1093/ps/79.2.205.

Sviatenko, N. A., \& Kucheriavy, V. T. (2016). Investigation of the influence of prebiotic on the rumen structure of young cattle. Topical Issues of Livestock and Fisheries Development. Materials Scientific and Practical Conference, Kiev, 97-99 (in Ukrainian).

Tarasenko, N. A., \& Filippova, E. V. (2014). A brief on prebiotics: history, classification, receipt, application . Fundamental Research, 6, 1-5 (in Russian).

Uyeno, Y., Shigemori, S., \& Shimosato, T. (2015). Effect of Probiotics/Prebiotics on Cattle Health and Productivity. Microbes Environ, 30(2), 126-132. doi: 10.1264/jsme2.ME14176.

Van Loo, J., Coussement, P., de Leenheer, L., Hoebregs, H., \& Smits, G. (1995). On the presence of inulin and oligofructose as natural ingredients in the Western diet. Crit. Rev. Food. Sci. Nutr., 35(6), 525-552. doi: 10.1080/10408399509527714.

Vetvicka, V., \& Yvin, J. (2004). Effects of marine $\beta$ 1,3 glucan on immune reactions. Int. Immunopharmacol., 4(6), 721-730. doi: 10.1016/j.intimp.2004.02.007.

Watzl, B., Girrbach, S., \& Roller, M. (2005). Inulin, oligofructose and immunomodulation. Brit. J. Nutr., 93(1), 49-55. doi: 10.1079/bjn20041357.

Wójcik, R., Trapkowska, S., \& Małaczewska, J. (2007). Influence of $3-1,31,6-D-$ glucan on non-specific cellular defence mechanisms in lambs. Med. Veter., 63(1), 84-86. 